\title{
Testing of Bacterial and Fungal Isolates from Rumen Fluid Used in Inoculants in the Fermentation of Feed from Agro-Industrial Waste
}

\author{
Jamila Mustabi i* Zulkharnaim², Tutik Kuswinanti ${ }^{3}$, Sitti Nurani Sirajuddin ${ }^{4}$, \\ Abdel Razzaq Al-Tawaha ${ }^{5}$ \\ 1 Nutrition and Feed Department, Faculty of Animal Science, Hasanuddin University, Makassar, Indonesia \\ 2 Animal Production Department, Faculty of Animal Science, Hasanuddin University Makassar, Indonesia \\ ${ }_{3}$ Pest and Plant Diseases Department, Faculty of Agriculture, Makassar, Hasanuddin University, Indonesia \\ ${ }^{4}$ Socio-Economics Husbadry Department, Faculty of Animal Science, Hasanuddin University Makassar, Indonesia \\ ${ }^{5}$ Department of Crop Science, Faculty of Agriculture, Universiti Putra Malaysia 43400 UPM Serdang, \\ Selangor, Malaysia \\ * Corresponding author's e-mail: jamila@unhas.ac.id
}

\begin{abstract}
The addition of the inoculant can accelerate the fermentation process and improve the quality of the feed material in fermentation. This study aimed to isolate, test and select the rumen microorganisms that have high ability to degrade the fiber and improve the quality of materials used in inoculants to ferment agricultural wastes as alternative feed. Microbial isolate was extracted from cattle rumen fluid. The isolates type of fungus were grown on Potato Dextrose Agar (PDA) while the bacteria was grown on Nutrient Agar (NA) medium. Microbes of fungi were tested and selected based on their ability to produce ligninase, cellulase and hemicellulase enzymes. Bacteria were grown on MRS broth media as a confirmation for LAB colonies, then tested for gram staining, catalase test, growth on different $\mathrm{NaCl}$ levels (4 and 6.5\%) and growth at various $\mathrm{pH}(3,4$, and 5$)$. The results showed that five fungal isolates had a growth diameter of $0.1-0.37 \mathrm{~mm}$ on lignin, cellulose and hemicellulose media after seven days. Eleven bacterial isolates were indicated as lactic acid bacteria; almost all isolates could grow on $\mathrm{NaCl} 6.5 \%$, but only four bacterial isolates could grow on $\mathrm{NaCl} 4 \%$ and five bacterial isolates could grow at $\mathrm{pH} 3$. In conclusion, three isolates of fungi have a remarkable ability to degrade lignin. Five isolates of lactic acid bacteria have a comprehensive ability as a preservative in fermentation, so eight microbial isolates from rumen fluid can be used as inoculants in fermenting the feed material from agro-industrial waste.
\end{abstract}

Keywords: rumen fluid microorganism, fiber decomposing fungi, lactid acid bacteria.

\section{INTRODUCTION}

Livestock productivity is determined by the quality and quantity of available feed, especially during the dry season. Low crude protein and high crude fiber in feed causes that the basic living needs of livestock are not fulfilled, thus reducing the efficiency of feed and animal health. Meanwhile, the remaining agricultural, plantation and food processing industries are abundant. The abundant by-product of the agricultural industry is the advantage of feed in Indonesia, because the price is relatively cheap, it is wide-spread and not used by humans as food, but contains high lignocellulose and low crude protein. Dashtban et al., (2009) stated that lignocellulose is an organic component, which consists of three polymers, namely cellulose, hemicellulose and lignin. The low nutrient content of feed ingredients from agricultural waste can be increased by processing it into quality feed that increases livestock productivity.

The basic principle of increasing lignocellulosic digestibility is the release of lignin bonds with cellulose, hemicellulose, protein and other compounds, to increase the digestibility value of waste using appropriate microbes through a process of 
enrichment, isolation, selection and identification (Bachruddin, 2014). On the basis of the consideration that ruminants are able to convert low-quality to high-quality feed due to the role of lignocellulotic microbes, it is important to isolate it to obtain rumen microbial isolates (bacteria and fungi) that have high ability to digest crude fiber in feed from agricultural, industrial and plantation waste. Before using agro-industrial waste as feed, it is necessary to enrich its components and increase the quality through biological treatment, with a fermentation process using rumen microbes as inoculants.

Cows rumen fluid has the potential as a feed additive because it contains a large microbial population. Of all rumen microbes, fungi are microbes that have the ability to degrade lignified cell walls (Abdullah et al. 1990), which is about $8 \%$ of fungi from the total microbial mass (Orskov and Ryle, 1990). Ruminants consuming forage with a greater proportion have a population of fungi in the rumen from $10^{4}$ to $10^{5}$ per $\mathrm{ml}$ of rumen fluid. Cattle have high digestibility of fiber, so it is possible that the rumen fluid contains lactic acid bacteria which have the potential to be biopreservative and inoculant in fermentation of fibrous feed ingredients (Nurhalimah et al, 2015; Jasin and Bachrudin, 2013). The digestive tract of ruminants (cows) is known to have microorganisms; the colon is a place of abundance of LAB, especially Bifidiobacterium spp, estimated at $10^{8}-10^{11}$ per gram (Salminen and Wright, 1998).

Rumen microbes work in a mixed system, unable to work in a pure system alone (Van Soest, 1994). Yokohama and Johnson (1988) added that the interactions between microbes affect the presence of these microbes in the rumen. The fermentation of complex carbohydrates, such as cellulose, can be increased by the interaction between microbes (Baldwin and Allison, 1983). Fonty (1991) states that mixed fungal populations can digest up to $60 \%$ of plant tissue. Mixed protozoan populations without bacteria can digest $7 \%$ cellulose. Mixed bacterial populations can digest $40 \%$ cellulose during the same time, if both are present in optimal proportions will increase the ability to digest cellulose by up to 60\% (Orskov and Ryle, 1990).

Processing of feed by fermentation or silage can use a fermenter inoculum derived from only one type of strain (single) or consortium (mixed inoculum) aims to accelerate the fermentation process and yield the best results. Inoculum (starter culture) can be obtained from commercial products or from the results of self-isolation. The use of additives in feed can improve the silage quality (Parakkasi, 1999). The purpose of additives in silage making is to accelerate the formation of lactic and acetic acids to prevent the formation of undesirable fermentation, as well as a nutritional supplement in fermented feed. In order to avoid unsuccessful fermentation, it is recommended to add a homofermentative lactic acid bacteria inoculum (LAB), to ensure the occurrence of lactic acid fermentation. LAB is the most popular additive compared to acids, enzymes or others (Bolsen et al., 1995). Because of the importance of using inoculants in accelerating the fermentation process in improving the quality of feed from agro-industrial waste, it is necessary to isolate microbes from decomposing fungi and bacteria that produce lactic acid from the rumen fluid. Isolation and testing were conducted to obtain the fungal isolates that have a high ability to degrade fiber and lactic acid-producing bacteria which can be used as inoculants in fermenting agricultural waste as alternative feed.

\section{MATERIALS AND METHODS}

\section{Source of microbes}

The rumen fluid used as a source of microbes was taken from the Slaughterhouse in Makassar City. The dilution process was carried out by taking $1 \mathrm{ml}$ of rumen fluid and suspending it into 10 $\mathrm{ml}$ of sterile distilled water, shaking it and making a $10^{-1}$ to $10^{-9}$ dilution series into a separate test tube. The concentration of the suspense sample was taken in one $\mathrm{ml}$ each and then poured into a petri dish containing PDA (Potato Dextro Agar). Chlorampenicol medium was used to grow fungi, while NA (Nutrient Agar) medium and cyclohexamide were employed to grow bacteria in a petri dish. The samples grown in PDA media were incubated for 3-7 days at room temperature, while the samples grown in NA were incubated for 2448 hours (Agustini 2011). Every single colony that grew on the isolation plate, was immediately subcultured to new media to obtain pure culture. A single dish contained only one microbial colony.

\section{Isolation and testing of fiber- decomposing fungi}

Screening of ligninase-producing isolates. Testing of ligninase-producing isolates aimed to 
test the presence of lignin (ligninase) degrading enzymes, namely lignin peroxidase and lacase, a spot test was carried out by dropping a $1.0 \%$ pyrogallol solution mixed with $0.4 \% \mathrm{H}_{2} \mathrm{O}_{2}(1: 1)$. The brownish yellow color of the pyrogallol reagent drops indicates the activity of the enzyme lignin peroxidase. The laccase enzyme was detected using $0.1 \mathrm{M}$ 1-naphthol reagent diluted with $96 \%$ ethanol. Purplish red color is a positive indicator of the laccase enzyme (Stalpers, 1978).

Screening of cellulase-producing isolates. Testing of cellulase-producing isolates using selective carboxymethycellulose (CMC) agar, containing $0.2 \% \mathrm{NaNO}_{3}, 0.1 \% \mathrm{~K}_{2} \mathrm{HPO}_{4}, 0.05 \%$ $\mathrm{MgSO}_{4}, 0.05 \% \mathrm{KCL}, 0.2 \%$ sodium salt CMC, $0.02 \%$ peptone and $1.7 \%$ Difco agar. The formation of a transparent zone around the fungus colony identifies the activity of the cellulase enzyme produced by the fungus (Kasana et al., 2008).

Screening of hemicellulase-producing isolate. Testing of hemicellulase-producing isolates was carried out by culturing pure isolates aged 7 days into Czapek medium (Difco ${ }^{\mathrm{TM}}$ ) enriched by providing $0.2 \%$ xylan as a single carbon source (Zhang et al., 2005) and incubated at $30^{\circ} \mathrm{C}$ for one week. After 7 days of incubation, the clear zone area around the fungal colony was observed and measured. The formation of a transparent zone around the fungal colony identifies the activity of the hemicellulase enzyme produced by the fungus.

The enzyme activity was tested to determine its ability to degrade fiber (lignocellulose) qualitatively (Coughlan, 1988). Selection was based on the ratio of the highest clear zone to the diameter of the colonies planted (Kluepfel, 1988).

\section{Isolation and testing of lactic acid bacteria}

Bacterial growth on selective media de Mann Rogoss Sharpe (MRS) Agar refers to Suardana et al. (2009). Testing and identification were carried out as a confirmation stage for LAB colonies growing on MRS broth media. Morphological identification was performed by observing isolates growing on MRSA media taking into account the colony shape, elevation, edges and color of the bacterial colony.

\section{Gram test for bacteria}

Mixing one loop of bacterial isolate was performed on a slide that were dropped $10 \mu \mathrm{L}$ of $3 \%$
$\mathrm{KOH}$;. If mucus was formed, the bacteria were grouped into Gram negative, but if no mucus was formed the bacteria were grouped into Gram positive (Kurnia et al. 2016).

\section{Test for bacterial growth at different $\mathrm{NaCl}$ levels (4\% and 6.5\%)}

Bacterial isolates were inoculated on MRS broth media that had been added with $\mathrm{NaCl}$ with a concentration of $4 \%$ and $6.5 \%$ and then incubated at $35^{\circ} \mathrm{C}$ for 24 hours, the growing bacteria were marked by the turbidity of MRS broth media (Susilawati, 2016).

\section{Test for bacterial growth at various $\mathrm{pH}$ values ( $\mathrm{pH} \mathrm{3,4}$ and 5)}

The bacteria grown in MRS broth that has been set $\mathrm{pH}$ using concentrated $\mathrm{HCl}$ (acid) and $\mathrm{NaOH}$ (wet) were homogenized using a vortex and incubated at a temperature of $39^{\circ} \mathrm{C}$ for 48 hours (Hadioetomo, 1985), the bacteria that grew were marked by media turbidity, and the level of turbidity was measured using a spectrometer.

\section{Enzyme test (cellulase, chitinase and pectinase)}

Enzyme tests using CDA media (Czapex dox broth) added with cellulase, chitinase and pectinase enzymes were adjusted to the test; one loop of bacterial isolate was inserted into the media and incubated at room temperature for 48 hours. The enzyme-producing bacteria were marked by a clear zone on the edge of the bacterial colony.

\section{RESULTS AND DISCUSSION}

\section{Testing of fungi isolated from rumen fluid}

The results of the observation were 16 isolates of fungi from rumen fluid that could grow on PDA media. The isolates were purified and tested for growth on lignin media as the initial stage of selection, then their growth diameter on a petri dish was observed, and 5 best isolates were obtained. Furthermore, the 5 selected isolates were tested for their ability to produce ligninase, cellulase and hemicellulase enzymes. The growth diameter of 5 fungal isolates in producing enzymes can be seen in Table 1 . 
Table 1. Average growth diameter of fungal isolates on lignin, cellulose and hemicellulose media

\begin{tabular}{|c|c|c|c|c|}
\hline \multirow{2}{*}{ No } & \multirow{2}{*}{$\begin{array}{c}\text { Sample } \\
\text { Code }\end{array}$} & \multicolumn{3}{|c|}{ Growth diameter $(\mathrm{mm})$} \\
\cline { 3 - 5 } & & Lignin & Selulosa & Hemiselulosa \\
\hline 1 & $\mathrm{Cr} 10^{11}$ & 0.20 & 0.20 & 0.30 \\
\hline 2 & $\mathrm{Cr} 10^{4} 3$ & 0.23 & 0.13 & 0.20 \\
\hline 3 & $\mathrm{Cr} 10^{3} 2$ & 0.35 & 0.20 & 0.20 \\
\hline 4 & $\mathrm{Cr} 10^{1} 3$ & 0.30 & 0.37 & 0.20 \\
\hline 5 & $\mathrm{Cr} 10^{2} 3$ & 0.33 & 0.15 & 0.30 \\
\hline
\end{tabular}

In the lignin test, the largest clear zone of the Cr 1032 isolate, indicated that it had a higher potential to produce ligninase enzymes. The higher the resulting lignocellulolytic index, the greater the enzyme produced by the fungal colony. The size of the lignocellulolytic index shows the size of the isolate's ability to degrade lignocellulose (polysaccharide compounds). The resulting lignocellulolytic index reflects the activity of enzymes in degrading lignocellulose.

Selection of fungal isolates was performed through testing the ability of the fungus to degrade fibers in a medium containing $\mathrm{CMC}$, xylan, lignin and mannan. They were selected to produce the fungal isolates able to utilize the existing carbon source (CMC, xylan, lignin and manan). It can be seen from the clear zone formed around colonies of fungi area. The clear zone formed indicates that the fungal isolate produces cellulase, xylanase, manannase and ligninase enzymes to degrade lignocellulose. The potential isolates of lignocellulolytic fungi were shown by the wide clear zone formed and the high hydrolysis index in the broth medium containing lignocellulose (CMC, xylan, manan and lignin).

The test results showed that the differences in species of fungi affect the size of the enzyme activity which is derived from the ratio of the clear zone (lignoselulolitik index). In accordance with the statement of Kusnadi (2010), the ability to produce enzymes in each fungus is specific to species and even strains.

In Table 1 it can be seen that 5 fungal isolates produce clear zones in cellulose testing, indicating that these isolates have the potential to be cellulase-producing fungi. On the basis of the qualitative test results, it was found that the average diameter size of the clear zone in isolates was from the smallest $0.1 \mathrm{~mm}$ to the largest 0.37 $\mathrm{mm}$ size. The size of the clear zone is an early indication of cellulase produced. The larger the clear zone produced, the greater the possibility of cellulase produced or higher enzyme activity. Observations of white fringe fungi isolates were conducted by Hartana (2014), who reported that the colony was light colored with mycelium like cotton. According to Adlini (2014), Aspergillus is a type of fungus that can grow on media that contains cellulose. According to Jalil (2004), Aspergillus can degrade cellulose and produce cellulase excreted at the tips of the hyphae to degrade the polymer nutrients optimally.

The average ability of fungal isolates from rumen fluid to degrade hemicellulose is shown in Table 1. The results showed that 5 fungal isolates produced clear zones, so these isolates have the potential to be hemicellulose-producing fungi. This shows a positive reaction to the hemicellulose-degrading enzyme test. Hemicellulose has a very complex structure, consisting of various types of sugars. The largest component of hemicellulose constituent sugars is xylan (Kubata et al., 1994; Saha, 2002). The chemical structure of hemicellulose consists of the main chain (backbone) in the form of D-xylopira-nose homopolymers which are connected to each other by $\beta-1,4$ D-glycosidic bonds (Saha, 2002) and branch chains in the form of o-acetyl, $\alpha-\mathrm{L}$ -arabinofuranosyl, D-glucoronyl and o-methylD-glucoronyl (Ali et al., 2004; Kubata et al., 1994; Saha, 2002). The breakdown of hemicellulose (xylan) involves two enzymes, namely endo- $\beta$ - $1,4-$ xylanase and $\beta$-xylosidase.

From the results of several tests carried out on fungal isolates, three isolates were best used as inoculants in fermenting the feed ingredients from agro-industrial waste, namely $\mathrm{Cr} 1032, \mathrm{Cr}$ 1023 and $\mathrm{Cr} 1043$. The criteria for the best fungal isolates are high ability to degrade lignin and low degradability against cellulose and hemicellulose in feed ingredients. Murni, et al. (2008) stated that the microorganisms that have great ability to decompose lignin but have low degradation of cellulose and hemicellulose are ideal in the bioconversion of lignocellulose into animal feed.

\section{Testing of lactic acid bacteria isolated from rumen fluid}

The observation showed 11 bacterial isolates from rumen fluid that grew after planting on MRS broth media. The isolates were purified and morphological bacterial colonies were identified. Biochemical tests that took into account the gram of bacteria, tolerance of bacteria 
Table 2. Results of the morphological identification test of lactic acid bacteria isolates

\begin{tabular}{|c|c|c|c|c|c|}
\hline \multirow{2}{*}{ No. } & \multirow{2}{*}{ Code } & \multicolumn{4}{|c|}{ Morphology of bacteria } \\
\cline { 3 - 6 } & & Form & Elevation & Edge & Color \\
\hline 1 & BR1 & Cirkular & Raised & Lobed & Yellowish white \\
\hline 2 & BR2 & Irregular & Raised & Wary & Yellowish white \\
\hline 3 & BR3 & Irregular & Raised & Wary & Yellowish white \\
\hline 4 & BR4 & Irregular & Raised & Curly & Yellowish white \\
\hline 5 & BR5 & Cirkular & Raised & Entire & Yellowish white \\
\hline 6 & BR6 & Cirkular & Convex & Entire & Milky white \\
\hline 7 & BR7 & Cirkular & Convex & Entire & Milky white \\
\hline 8 & BR8 & Cirkular & Convex & Entire & Milky white \\
\hline 9 & BR9 & Cirkular & Raised & Wary & Yellowish white \\
\hline 10 & BR10 & Irregular & Flat & Jogged & Yellowish white \\
\hline 11 & BR11 & Cirkular & Convex & Entire & Milky white \\
\hline
\end{tabular}

to $\mathrm{NaCl}$ levels and at controlled $\mathrm{pH}$ and enzyme testing (cellulase, pectinase and chitinase) of bacteria were conducted.

Identification of bacterial colonies was carried out by observing the physical colony of bacteria, paying attention to the shape, color, elevation and edges of the bacterial colony. The results of identification of bacterial colonies can be seen in Table 2 .

The results of identification of the bacterial colonies isolated from cattle rumen fluid showed that each bacterial colony had a different shape, elevation, color and edges. The difference in colony morphology indicated that each isolate came from a different species. The morphology of bacterial colonies needs to be observed to facilitate the identification process of bacteria, because the properties of bacterial colonies can determine the type of bacteria (Lay, 1994). From several types of colonies found, it was suspected that all bacterial isolates were lactic acid bacteria, because they could grow on the MRS broth media. The results of observations of isolates that have creamy or milky white color are lactic acid bacteria; this is in accordance with the results of research by Delfahedah et al. (2013) who found several isolates of lactic acid bacteria isolated from soursop fruit, namely in the form of round colonies, smooth edges, convex elevation as well as milky white and cream colors.

Bacterial biochemical tests were carried out by observing the gram of bacteria, bacterial tolerance to $\mathrm{NaCl}$ levels (4\% and $6.5 \%)$ and bacterial resistance at a controlled $\mathrm{pH}(\mathrm{pH} 3, \mathrm{pH} 4$ and $\mathrm{pH}$ 5). The results of bacterial biochemical tests can be seen in Table 3 .
The results of the gram analysis showed that 11 bacterial isolates from the rumen fluid were gram-positive bacteria, gram-positive bacteria were characterized by no mucus formed by the bacteria after being dripped with $\mathrm{KOH}$, had thick cell walls and thin fat, while gram-negative bacteria had thick fat and cell walls. Thin in the periplasmic space (Kurnia, et al. 2016), KOH will attack the fat (lipid bilayer) and make gram (-) cells burst. The broken cell will release genetic material (DNA) which is an abundant substance in bacterial cells. Very long DNA molecules are sticky strings (resembling mucus, gummy or sticky) which are slimy when removed with an inoculum needle (Edwin, 2011).

The results of the bacterial tolerance test to $\mathrm{NaCl}$ levels (4\% and 6.5\%) showed that the BR7,

Table 3. Biochemical test results for bacteria isolated from cattle rumen fluid

\begin{tabular}{|c|c|c|c|c|c|c|c|}
\hline \multirow{2}{*}{ No } & \multirow{2}{*}{ Code } & \multicolumn{5}{|c|}{ Testing } \\
\cline { 4 - 8 } & & \multirow{2}{*}{ Gram } & \multicolumn{2}{|c|}{$\mathrm{NaCl}$} & \multicolumn{3}{c|}{$\mathrm{pH}$} \\
\cline { 4 - 8 } & & $4 \%$ & $6.5 \%$ & 3 & 4 & 5 \\
\hline 1 & BR1 & + & - & + & + & + & + \\
\hline 2 & BR2 & + & - & + & - & + & + \\
\hline 3 & BR3 & + & - & + & - & - & + \\
\hline 4 & BR4 & + & - & + & - & + & + \\
\hline 5 & BR5 & + & - & + & - & + & + \\
\hline 6 & BR6 & + & - & + & + & - & + \\
\hline 7 & BR7 & + & + & + & + & + & - \\
\hline 8 & BR8 & + & + & - & + & - & + \\
\hline 9 & BR9 & + & - & + & - & - & + \\
\hline 10 & BR10 & + & + & + & - & - & + \\
\hline 11 & BR11 & + & + & + & + & + & + \\
\hline
\end{tabular}

Note: - (no reaction); + (reaction) 
$\mathrm{BR} 8, \mathrm{BR} 10$ and BR11 bacteria were tolerant to $4 \% \mathrm{NaCl}$ construction, while in the $\mathrm{NaCl}$ concentration of $6.5 \%$ there were 10 bacteria that could survive except for BR8 isolates. Salt tolerance test determine the level of resistance of bacterial isolates to bile salts that must be passed in order to reach the intestines and carry out metabolic activity, so as to balance the microflora in digestion (Thakkar et al., 2015).

The results of testing for bacterial resistance at controlled $\mathrm{pH}(\mathrm{pH} 3, \mathrm{pH} 4$ and $\mathrm{pH} 5)$ can be seen in Table 2. Most bacteria can grow at $\mathrm{pH} 5$ conditions and only a few types of bacteria can grow at $\mathrm{pH} 3$ and 4 . The lower the $\mathrm{pH}$, the lesser the number of isolates that escape. This is influenced by the lower $\mathrm{pH}$ conditions which cause disruption of bacterial activity to grow. The effect of $\mathrm{pH}$ on bacterial growth is related to enzyme activity to catalyze the reactions associated with bacterial growth. If the $\mathrm{pH}$ of bacterial growth is not optimal, it will disrupt the bacterial growth (Respati, 2017).

The bacterial enzyme test was carried out by growing bacterial isolates on CDA media modified by cellulase, pectinase and chitinase. The isolates that produced a clear zone around the colony indicated that the enzymes suitable for the modified medium were produced. The results of the bacterial enzyme test can be seen in Table 4 .

Enzyme-producing bacteria were characterized by the appearance of clear zones on modified CDA media. In the cellulase specification media, there are several bacteria that can produce enzymes, the size of the clear zone indicates that bacteria have different abilities to produce enzymes. This is related to the ability of bacteria to hydrolyze cellulose into glucose, in accordance with the

Table 4. Diameter of bacterial growth on enzyme tests (cellulase, pectinase and chitinase)

\begin{tabular}{|c|c|c|c|c|}
\hline \multirow{2}{*}{ No } & \multirow{2}{*}{$\begin{array}{c}\text { Bakteri } \\
\text { Code }\end{array}$} & \multicolumn{3}{|c|}{ Enzyme } \\
\cline { 3 - 5 } & Selulase & Pectinase & Kitinase \\
\hline 1 & BR1 & - & - & - \\
\hline 2 & BR2 & $10 \mathrm{~mm}$ & $3 \mathrm{~mm}$ & $12 \mathrm{~mm}$ \\
\hline 3 & BR3 & $12 \mathrm{~mm}$ & $6 \mathrm{~mm}$ & $11 \mathrm{~mm}$ \\
\hline 4 & BR4 & $9 \mathrm{~mm}$ & $4 \mathrm{~mm}$ & $6 \mathrm{~mm}$ \\
\hline 5 & BR5 & $10 \mathrm{~mm}$ & $3 \mathrm{~mm}$ & $5 \mathrm{~mm}$ \\
\hline 6 & BR6 & $10 \mathrm{~mm}$ & $4 \mathrm{~mm}$ & $5 \mathrm{~mm}$ \\
\hline 7 & BR7 & - & - & $6 \mathrm{~mm}$ \\
\hline 8 & BR8 & $5 \mathrm{~mm}$ & - & - \\
\hline 9 & BR9 & $9 \mathrm{~mm}$ & $6 \mathrm{~mm}$ & $5 \mathrm{~mm}$ \\
\hline 10 & BR10 & $9 \mathrm{~mm}$ & - & $13 \mathrm{~mm}$ \\
\hline 11 & BR11 & - & - & $5 \mathrm{~mm}$ \\
\hline
\end{tabular}

opinion of Rahayu, et al. (2014) who stated that the bacterial isolates that have high cellulase enzyme activity can hydrolyze cellulose to glucose and show a large clear zone around the colony, due to the changes in the structure of cellulose from fibrous to glucose with the structure being non-fiber.

The pectinase activity of bacterial isolates can be seen in Table 3 . The ability of bacteria to produce clear zones on pectinase-specific media identifies that these bacteria have the ability to produce the pectinase enzyme. The larger the clear zone produced by the bacterial isolate, the greater the ability of the bacteria to produce the pectinase enzyme. In the test of chitinase-producing bacteria, there are several bacteria that can produce clear zones. The clear zone is formed due to the process of breaking the chitin substrate into simple compounds after chitinase is secreted by bacteria (Suryadi et al., 2013).

The results of the selection from tests carried out on bacterial isolates from rumen fluids as inoculants in the fermentation of feed ingredients obtained the five best isolates, namely BR6, BR7, BR8, BR10 and BR11. The addition of lactic acid bacteria as an inoculant in fermentation is used to prevent the growth of destructive bacteria during the fermentation process. Lactic acid bacteria can produce nisin as bacteriocin, which is a biopreservative compound that can prevent the growth of destructive bacteria or even pathogenic bacteria (Ray, 1992).

\section{CONCLUSIONS}

There are three fungal isolates that can be used as inoculants in fermenting feed ingredients from waste, namely $\mathrm{Cr} 10^{3} 2, \mathrm{Cr} 10^{2} 3$ and $\mathrm{Cr} 10^{4} 3$, the three isolates show great ability in degrading lignin. The five best isolates of lactic acid bacteria were obtained, which had quite a wide ability as a preservative in the fermentation of feed ingredients from agro-industrial waste, namely BR6, BR7, BR8, BR10 and BR11.

\section{REFERENCES}

1. Abdullah H., Ho Y.W., Jalaludin. 1990. Role of Rumen Microbes in the Breakdown of agricultural by products. Proceeding of workshop pn Research Methologies, 115-125.

2. Adlini N.I. 2014. Seleksi mikroba seluloitik dalam mendegradasi lignin asal tanah gambut Desa 
Rimbo Panjang Kampar Riau. Jurusan Biologi. Fakultas Matematika dan Ilmu Pengetahuan Alam. Universitas Riau. Riau.

3. Ali M.K., Rudolph F.B., Bennet G.N. 2004. Thermostable xyla-nases $10 \mathrm{~B}$ from Clostridium acetobotylicum ATCC824. J. Ind. Micro-biol. Technol., 31, 229-234.

4. Baldwin R.L., Allison M.J. 1983. Rumen metabolism. Journal Animal Science, 57(2), 461-477.

5. Bolsen K.K., Ashbell M.G., Wilkinnson J.M. 1995. Silage Aditifs in Biotechnology in Animal Feeding. R.J. Wallace \& A. Chesson (Eds). VCH, Weinheim.

6. Coughlan M.P. 1988. Staining Tecniques for The Detection of The Individual Components of Cellulolytic Enzyme Systemes. In: Wood, W.A. and Kellogg. S.T. (Eds) Methods In Enzymology, Academic Press, London, 160, 135-144.

7. Dashtban M., Schraft H., Qin W. 2009. Fungal Bioconversion of Lignocellulosic Residue: Opportunities \& Perspectives. Int. J. Biol. Sci., 578-595.

8. Delfahedah Y., Syukur S., dan Jamsari. 2013. Isolasi karakterisasi dan identifikasi DNA Ciprofloxacin FBK 3 FBK 1 FBK 1 FBK 2 FBK 3 Ciprofloxacin BIOLEUSER, bakteri asam laktat (BAL) yang berpotensi sebagai antimikroba dari Fermentasi kakao varietas hibrid (Trinitario). Jurnal Kimia Unand, 2(4).

9. Edwin. 2011. Materi Kuliah Mikrobiologi. Banjarbaru (ID): Universitas Lambung Mangkurat.

10. Fonty G. 1991. The Rumen Anaerobic Fungi. In: Rumen Microbial Metabolism and Ruminant Digestion. Institut national De La Recherche Agronomique Paris.

11. Hadioetomo R.S. 1985. Mikrobiologi dasar-dasar praktik. PT. Gramedia, Jakarta.

12. Hartana S.N. 2014. Keanekaragaman Cendawan yang Diisolasi di Lokasi Perkandangan Ayam. Institut Pertanian Bogor. Bogor.

13. Jalil A.A.K. 2004. Enzim Mikroba dan Bahan Penguraian Berselulosa. Departemen Biologi. Jakarta.

14. Jasin I., dan Bachrudin Z. 2013. Pengaruh isolate bakteri asam laktat dari feses pedet sapi perah baru lahir terhadap produksi asam laktat dan perubahan pH pada ampas tahu. J. Agripet., 13(2), 36-40.

15. Jouany J.P. 1991. Rumen Microbial Metabolism and Ruminant Digestion. Institute National De La Recherche Agronomique, 147, Rue De I'Universite-75338 Paris Cedex 07.

16. Kasana R.C., Salwan R., Dhar H., Dutt S., Gulati A. 2008. A. Rapid and easy method for detection of microbial cellulases on agar plates using Gram's iodine. Curr. Microbiol., 57, 503-507.

17. Kluepfel D. 1988. Screening Of Prokaryotes For Cellulose And Lignocellulose as A Sources of Inoculum Fermented to High Fibre Feed. Pakistan Journal of Nutrition, 12(9), 851-853.
18. Kubata B.K., Suzuki T., Horitsu H., Kawal K., Takamizawa K. 1994. Purification and characterization of Aeromonas caviae ME-1 xylanases V, which produces exclusively xylobiose from xylan. Applied \& Environmental Microbiology, 60, 531-535.

19. Kurnia K., Sadi N.H., dan Jumianto S. 2016. Isolasi bakteri heterotrof di situ cibuntu, jawa barat dan karakterisasi resistensi asam dan logam. http://journal.uinjkt.ac.id/index.php/kauniyah AL-KAUNIYAH; Journal of Biology, 9(2), 2016, 74-79.

20. Kusnadi. 2010. Keanekaragaman Jamur Selulolitik Dan Amilolitik Pengurai Sampah Organik Dari Berbagai Substrat. Jurusan Pendidikan Biologi Fpmipa Universitas Pendidikan Indonesia, 1-10.

21. Lay B.W. 1994. Analisa Mikroba Di Laboratorium. Edisi 1. Cetakan 1. Raja Grafindo Persada. Jakarta

22. Murni R., Suparjo, Akmal, dan Ginting B.L. 2008. Buku Ajar Teknologi Pemanfaatan Limbah untuk Pakan. Laboratorium Makanan Ternak. Fakultas Peternakan universitas Jambi.

23. Nurhalimah H., Wijayanti N., Widyaningsih T.D. 2015. Efek Antidiare Ekstrak Daun Beluntas ( Pluchea indica L.) Terhadap Mencit Jantan yang Diinduksi Bakteri Salmonella Thypimurium Antidiarrheal. Jurnal Pangan Dan Agroindustri, 3(3), 1083-1094.

24. Orskov E.R., Ryle M. 1990 Energy nutrition in ruminants. Elsevier Applied Science. London, 149.

25. Parakkasi, A.1999. Ilmu Nutrisi dan Makanan Ternak Ruminansia.Universitas Indonesia Press. Jakarta.

26. Rahayu A.G., Haryani Y., Fifi P. 2014. Uji aktivitas selulolitik dari tiga isolat bakteri bacillus sp. galur lokal riau. JOM FMIPA, 1(2).

27. Ray B. 1992. Nisin of Lactococcus lactissubsp. lactis as a Food Biopre-servative, 207-264. In: B. Ray andM. Daeschel (ed). Food Biopreser-vatives of Microbial Origin. CRC Press. Boca Raton.

28. Respati N.Y. 2017. Optimasi suhu dan $\mathrm{pH}$ media pertumbuhan bakteri pelarut fosfat dari isolat bakteri termofilik. Jurnal Prodi Biologi, 6(7).

29. Saha B.C. 2002. Purification and charachterization of an extracellular â- xylosidase from newly isolated Fu- sarium verticilloides. J. Ind. Micro- biol. Biotechnol., 27, 241-245.

30. Salminen S., Wright A. 1998. Lactic Acid Bacteria. Edisi ke-2. Marcel Dekker. Inc. New York. Basel.

31. Stalpers J.A. 1978. Identification of wood-inhabiting Aphyllophorales in pure culture. Centraalbureau Voor Schimmelcultures. Baarn. Studies in Mycology, 16, 1-248.

32. Suardana I.W., Suada I.K., Sukada I.M., Suarsana I.N. 2009. Isolasi danidentifikasi bakteri asam laktat SR9 asal cairan rumen sapi bali sebagai kandidat probiotik. J.Medicina., 40(2), 100-103. 
33. Suryadi Y., Priyatno T.P., Samudra M., Susilowati D.N., Lawati N., dan Kustaman E. Pemurnian parsial dan karakterisasi kitinase asal jamur entomopatogen beauveria bassiana isolat BB200109 2013. J. Agro Biogen., 9(2).

34. Susilawati S. 2016. Isolasi dan Karakterisasi Bakteri Asam Laktat (BAL) dari Fermentasi Air Cucian Beras. Skripsi. Jakarta: Fakultas Kedokteran dan Ilmu Kesehatan UIN Syarif Hidayatullah.

35. Thakkar P., Modi H.A., Prajapati J.B. 2015. Isolation, characterization and safety assessment of lactic acid bacterial isolates from fermented food products. International Journal of Current Microbiology and Applied Sciences, 4(4).

36. Van Soest P.J. 1994. Nutitional Ecology of The Ruminant. Cornell University Press. Ithaca. New York.

37. Yokoyama M.T., Johnson K.A. 1988. Microbiology of the rumen digestive physiology and nutrition. In : D.C. Church (Ed.), The Ruminant animal. Printice Hall, Englewood Cliifs, New Jersey, 125-144.

38. Zhang G.-L., Wu Y.-T., Qian X.-P., Meng Q. 2005. Biodegradation of crude oil by Pseudomonas aeruginosa in the presence of rhamnolipids. Journal of Zhejiang University Science, 6B, 725-730. 